\title{
Synthesis and Site Structure of a Replica Platinum-Carbon Composite Formed Utilizing Ordered Mesopores of Aluminum-MCM-41 for Catalysis in Fuel Cells
}

\author{
Kazuki Oka, ${ }^{\dagger}$ Yoshiyuki Shibata, ${ }^{\ddagger}$ Takaomi Itoi, ${ }^{\S}$ and Yasuo Izumi*, ${ }^{\dagger}$ \\ Department of Chemistry, Graduate School of Science, Department of Nanomaterial Science, Graduate School \\ of Advanced Integration Science, and Department of Mechanical Engineering, Graduate School of Engineering, \\ Chiba University, Yayoi 1-33, Inage-ku, Chiba 263-8522, Japan
}

Received: October 16, 2009

\begin{abstract}
Platinum nanoparticles have been reported with mean sizes between 1.5 and $7 \mathrm{~nm}$ supported on carbon. The contact between $\mathrm{Pt}$ nanoparticles and $\mathrm{C}$ has never been controlled and monitored nanoscopically. In this paper, stable Pt nanoparticles with a mean size of $1.2 \mathrm{~nm}$ were synthesized embedded on/in a $\mathrm{C}$ matrix catalytically produced from acetylene over the $\mathrm{Pt}$ nanoparticles. The replica $\mathrm{Pt}-\mathrm{C}$ composite was synthesized inside of the ordered mesopores $(2.7 \mathrm{~nm})$ of Al-MCM-41 followed by removal of the template. The contact between the $\mathrm{Pt}$ nanoparticle and $\mathrm{C}$ was experimentally observed by high-energy resolution $\mathrm{Pt} \mathrm{L}_{2}$-edge XANES spectra tuned to $11065.7 \mathrm{eV}$, at a lower energy by $5 \mathrm{eV}$ than the $\mathrm{Pt} \mathrm{L} \beta_{1}$ peak top for the replica $\mathrm{Pt}-\mathrm{C}$ pressed to electrolyte polymer (Nafion). The spectra were nicely reproduced in a theoretical spectrum using ab initio multiple scattering calculations for the interface Pt site between cuboctahedral $\mathrm{Pt}_{38}$ and graphite layers. Other $\mathrm{Pt}$ sites detected in state-selective $\mathrm{Pt} \mathrm{L}_{2}$-edge XANES were exclusively metallic for replica $\mathrm{Pt}-\mathrm{C} / \mathrm{Nafion}$ either in air or in $\mathrm{H}_{2}$. The thus-characterized replica $\mathrm{Pt}-\mathrm{C}$ composite was tentatively tested as a cathode of a $\mathrm{H}_{2}$ - air polymer electrolyte fuel cell in comparison to commercial $20 \mathrm{wt} \% \mathrm{Pt} / \mathrm{Vulcan} \mathrm{XC}-72$ as the cathode. The improvement of $\mathrm{Pt}$ dispersion stabilized on/in a $\mathrm{C}$ matrix, effective contact of $\mathrm{Pt}$ with $\mathrm{C}$, and diffusion of $\mathrm{O}_{2}$ in a few nanometers of replica $\mathrm{Pt}-\mathrm{C}$ powder was suggested.
\end{abstract}

\section{Introduction}

The control of platinum nanoparticle size between 1.5 and 7 $\mathrm{nm}$ supported on carbon is essential in the application to fuel cells ${ }^{1}$ and detoxification of exhaust gas from automobiles. ${ }^{2} \mathrm{Pt}$ nanoparticles on $\mathrm{C}$ nanofibers (mean Pt size of $1.7-4 \mathrm{~nm}$ ), ${ }^{3,4} \mathrm{C}$ nanotubes (mean Pt size of 2-6.7 nm), ${ }^{4-10}$ ordered mesoporous $\mathrm{C}$ (mean Pt size of $1.5-3 \mathrm{~nm}),{ }^{11-13} \mathrm{C}$ powder (mean Pt size of $1.6-4.8 \mathrm{~nm}){ }^{14-17}$ and spherical C (mean Pt size of $\left.2.9 \mathrm{~nm}\right)^{18}$ and Pt monolayer on nanoparticles of other metals ${ }^{19}$ have been synthesized in narrow particle size distribution.

The polymer electrolyte fuel cell (PEFC) is expected to be a portable and compact power source to start at atmospheric temperature and be operated at lower than $373 \mathrm{~K}$ for automobile and home use. ${ }^{20}$ In the design of PEFCs, the cathode catalyst for the oxygen reduction reaction $\left(\mathrm{O}_{2}+4 \mathrm{H}^{+}+4 \mathrm{e}^{-} \rightarrow 2 \mathrm{H}_{2} \mathrm{O}\right)$ is most critical because the physical contact of Pt with $\mathrm{C}$ (electric contact), the electrolyte (wet polymer to transport protons), and oxygen gas needs to be enabled at the same time. ${ }^{1}$ The morphologic effects of Pt nanoparticles, films, and alloys on the oxygen reduction reaction were reported. ${ }^{1,21}$ In contrast that the $\mathrm{Pt}$ nanoparticles have been formed on various types of controlled $\mathrm{C}$ materials, ${ }^{3-17}$ the electric contact of $\mathrm{Pt}$ with $\mathrm{C}$ has never been controlled and monitored nanoscopically.

In this work, the contact of $\mathrm{Pt}$ with $\mathrm{C}$ was controlled based on the idea of catalytic acetylene decomposition over $\mathrm{Pt}$ nanoparticles in a narrow size distribution centered at $1.2 \mathrm{~nm}$ formed inside of Al-exchanged ordered mesoporous silica Al-

* To whom correspondence should be addressed. E-mail: yizumi@ faculty.chiba-u.jp. Phone and Fax: +81-43-290-3696.

${ }^{\dagger}$ Graduate School of Science.

* Graduate School of Advanced Integration Science.

$\S$ Graduate School of Engineering.
MCM-41 to produce $\mathrm{Pt}-\mathrm{C}$ composites in mesopores. The replica $\mathrm{Pt}-\mathrm{C}$ composite was separated via the removal of $\mathrm{Al}-$ MCM-41 using hydrofluoric acid. The synthesis of the replica $\mathrm{Pt}-\mathrm{C}$ composite was monitored using high-resolution transmission electron microscope (TEM), X-ray diffraction (XRD), and Brunauer, Emmett, and Teller (BET) adsorption of $\mathrm{N}_{2}$. The local structure and heterogeneity of Pt sites were analyzed based on conventional $\mathrm{Pt}_{3}$ - and $\mathrm{L}_{2}$-edge $\mathrm{X}$-ray absorption fine structure (XAFS) and state-selective Pt L $\beta_{1}$-selecting $\mathrm{Pt} \mathrm{L}_{2}$-edge XAFS, respectively. State-selective XAFS was applied to Pt catalysts for the first time.

The Pt nanoparticles in a narrow size distribution centered at $1.2 \mathrm{~nm}$ are advantageous to use most of the Pt sites (80\%) for oxygen reduction; ${ }^{1}$ however, mass-specific activity for oxygen reduction is still under debate and/or critically depends on reaction conditions. The rate constant values were nearly constant for mean Pt particles between 1.6 and $4.8 \mathrm{~nm}$ on C. ${ }^{17}$ The mass-specific activity gradually decreased when the mean Pt particle size decreased from 30 to $1 \mathrm{~nm}^{22}$ or reached a maximum at $3.5 \mathrm{~nm} .^{23}$ The instability of Pt particles as small as $1 \mathrm{~nm}$ was suggested to be transformed into amorphous and less active. ${ }^{9}$ In this paper, stabilization of Pt nanoparticles (mean $1.2 \mathrm{~nm}$ ) was tried on/in a C matrix catalytically formed from acetylene in mesoporous space. The electronic structure of the interface Pt site between Pt nanoparticles and $\mathrm{C}$ was investigated. The replica $\mathrm{Pt}-\mathrm{C}$ was pressed as a tentative cathode catalyst of membrane electrolyte assembly (MEA).

\section{Experimental Section}

Synthesis. Ten milliliters of an $8.4 \mathrm{mM}$ aqueous solution of tetraammineplatinum(II) hydroxide hydrate $\mathrm{Pt}^{\mathrm{II}}\left(\mathrm{NH}_{3}\right)_{4}(\mathrm{OH})_{2} \cdot 2 \mathrm{H}_{2} \mathrm{O}$ (Strem Chemicals) and $1.0 \mathrm{~g}$ of Al-MCM-41 (molar ratio $\mathrm{SiO}_{2} /$ 
$\mathrm{Al}_{2} \mathrm{O}_{3}=0.9875 / 0.0125,1.11 \mathrm{wt} \% \mathrm{Al}$; Aldrich) were mixed and stirred at $353 \mathrm{~K}$ for 2 days. The suspension was filtered, washed, and heated in vacuum at $573 \mathrm{~K}$ for $2 \mathrm{~h}$. The obtained powder (Pt-Al-MCM-41, 1.3 wt \% Pt) was in a $30 \mathrm{~mL} \min ^{-1} \mathrm{H}_{2}$ $(>99.99 \% ; 101 \mathrm{kPa}$ ) flow at $573 \mathrm{~K}$ for $2 \mathrm{~h}$ and then in a $200 \mathrm{~mL}$ $\min ^{-1} \mathrm{C}_{2} \mathrm{H}_{2}(>98 \%)+\mathrm{N}_{2}(>99.999 \%)$ flow (molar ratio 1:9, total $101 \mathrm{kPa})$ at $973 \mathrm{~K}$ for $1 \mathrm{~h}$. The obtained black powder $(0.72 \mathrm{wt} \%$ $\mathrm{Pt})$ was treated with $30 \mathrm{~mL}$ of hydrofluoric acid $(15 \%$; special grade, Wako Pure Chemical) to give the replica $\mathrm{Pt}-\mathrm{C}$ composite $(0.84 \mathrm{wt} \% \mathrm{Pt})$. Fortunately, in view of electric conductivity, amorphous $\mathrm{C}$ dissolved in hydrofluoric acid, and $\mathrm{Pt}-$ graphite was preferably obtained. ${ }^{6,24}$ Somanathan et al. prepared Pt nanoparticles starting from hydrogen hexachloroplatinate(IV) in Al-MCM (molar ratio $\mathrm{SiO}_{2} / \mathrm{Al}_{2} \mathrm{O}_{3}=0.995 / 0.005$ ) followed by calcination at 823 $\mathrm{K}$. In $200 \mathrm{~mL} \mathrm{~min}^{-1}$ of $\mathrm{C}_{2} \mathrm{H}_{2}+\mathrm{N}_{2}$ flow (molar ratio 3:7), the start of $\mathrm{C}$ decomposition at $923 \mathrm{~K}$, carbon nanotube formation between 973 and $1073 \mathrm{~K}$, the maximum $\mathrm{C}$ decomposed at $1073 \mathrm{~K}$, and preferable formation of graphitic sheets and amorphous $\mathrm{C}$ at 1173 $\mathrm{K}$ were reported. ${ }^{6}$ The starting temperature of $\mathrm{C}$ decomposition and the maximum decomposed $\mathrm{C}$ yield were reproduced in this work, but we chose a relatively low temperature of $973 \mathrm{~K}$ for $\mathrm{C}_{2} \mathrm{H}_{2}$ decomposition to prevent the thermal growth of $\mathrm{Pt}$ nanoparticles.

Replica $\mathrm{Pt}-\mathrm{C}$ powder $(76 \mathrm{mg}$ ) was dispersed in $1.0 \mathrm{~mL}$ of $15 \%$ Nafion dispersion solution (DE2021-CS, Wako Pure Chemical) using ultrasonic treatment ( $85 \mathrm{~W}, 28 \mathrm{kHz})$ and was mounted on $190 \mu \mathrm{m}$ thick $\mathrm{C}$ paper coated with polytetrafluoroethylene (TGP-H-060H, Chemix). Similarly, $25 \mathrm{mg}$ of commercial 20 wt \% Pt supported on C (Vulcan XC-72, Cabot) was dispersed on TGP-H-060H using a 5-10\% Nafion dispersion solution. As a reference, mechanically dispersed Pt/Vulcan $\mathrm{XC}-72$ on TGP-H- $060 \mathrm{H}$ was also prepared. A $50 \mu \mathrm{m}$ thick electrolyte polymer Nafion film (NR-212, Dupont; >95\%; acid capacity $>9.2 \times 10^{-4}$ equiv $\mathrm{g}^{-1}$ ) was pressed with replica $\mathrm{Pt}-\mathrm{C} /$ TGP-H-060H as the cathode and 20 wt \% Pt/Vulcan XC-72/ TGP-H-060H as the anode for MEA. Another MEA was made using the same Nafion film pressed with $20 \mathrm{wt} \% \mathrm{Pt} /$ Vulcan $\mathrm{XC}-72 / \mathrm{TGP}-\mathrm{H}-060 \mathrm{H}$ on both sides. The area of the electrode catalysts was $5 \mathrm{~cm}^{2}$.

Characterization. Nitrogen adsorption measurements were performed at $77 \mathrm{~K}$ with the pressures between 1.0 and $90 \mathrm{kPa}$ in a vacuum system connected to diffusion and rotary pumps $\left(10^{-6} \mathrm{~Pa}\right)$ and equipped with a capacitance manometer (models CCMT-1000A and GM-2001, ULVAC). The samples were evacuated at $393 \mathrm{~K}$ for $2 \mathrm{~h}$ before measurements. Highresolution TEM images were taken using $\mathrm{LaB}_{6}$ source TEM equipment (JEOL, Model JEM-4000FX) with an accelerating voltage of $400 \mathrm{kV}$. Samples were dispersed in ethanol $(>99.5 \%$, Wako Pure Chemical) and mounted on amorphous C-coated copper mesh (CU150 Mesh, JEOL).

XRD data were obtained using a Rigaku MiniFlex diffractometer at a Bragg angle of $2 \theta_{\mathrm{B}}=2-10^{\circ}$ for ordered mesopores and $10-75^{\circ}$ for crystallites of $\mathrm{C}$ and Pt. The conditions involved were $30 \mathrm{kV}$ and $15 \mathrm{~mA}, \mathrm{Cu} \mathrm{K} \alpha$ emission, and a nickel filter. The replica $\mathrm{Pt}-\mathrm{C}$ powder and each intermediate composite during the synthesis were set in a dip of $18 \times 2 \times 1 \mathrm{~mm}^{3}$ on glass plate to measure the electric conductivity with the twopoint method. ${ }^{25}$

The powder samples for synchrotron X-ray measurements were prepared in the vacuum system $\left(10^{-6} \mathrm{~Pa}\right)$ and transferred in situ to a Pyrex glass cell equipped with $25-50 \mu \mathrm{m}$ thick Kapton (Dupont) windows on both sides. The samples in $\mathrm{H}_{2}$, air, or argon were sealed with fire and transported to the beamline. The replica $\mathrm{Pt}-\mathrm{C}$ powder was mounted on TGP-H$060 \mathrm{H}$, as described above, but pressed to only one side of Nafion
(NR-212) for synchrotron X-ray study. The Nafion and protection polyester films $(50 \mu \mathrm{m})$ were used as a window of Pyrex glass cells.

Conventional $\mathrm{Pt}_{\mathrm{L}_{3}}$ and $\mathrm{L}_{2}$-edge XAFS spectra were measured at $290 \mathrm{~K}$ in transmission mode in the Photon Factory at the High-Energy Accelerator Research Organization (Tsukuba, Japan) on beamlines 9C and 12C. The storage-ring energy was $2.5 \mathrm{GeV}$, and the ring current was between 450 and $250 \mathrm{~mA}$. A Si(111) double-crystal monochromator and cylindrical double mirror were inserted into the X-ray beam path. The parallelness of the double crystals was set to $65 \%$ intensity and to the maximum flux using a piezo translator. The slit opening size was $1 \mathrm{~mm} \times 1 \mathrm{~mm}$ in front of the $I_{0}$ ionization chamber. The $I_{0}$ and $I_{\mathrm{t}}$ ionization chambers were purged with the mixture of $\operatorname{Ar}(15 \%)+\mathrm{N}_{2}(85 \%)$ and Ar, respectively. The scan steps were $\sim 7.8, \sim 0.46$, and $\sim 2.5 \mathrm{eV}$ in the pre-edge, edge, and postedge regions, respectively. The accumulation time was $1-10 \mathrm{~s}$ for a data point. The $\mathrm{Pt}_{3^{-}}$and $\mathrm{L}_{2}$ absorption edge energy values were calibrated to 11562 and $13272.3 \mathrm{eV}$, respectively, for the spectra of Pt metal. ${ }^{26,27}$

State-selective Pt $\mathrm{L}_{2}$-edge XAFS measurements were performed at $290 \mathrm{~K}$ at the beamline $37 \mathrm{XU}$ of SPring-8 (Sayo, Japan). The storage ring energy was $8 \mathrm{GeV}$ at the top-up ring current of $100 \mathrm{~mA}$. A Si(111) monochromator and rhodiumcoated mirror were used. The undulator gap was optimized to maximize the X-ray beam flux at each data point. To stabilize the X-ray beam position on the surface of the sample, the monochromator stabilization mechanism was used. ${ }^{28}$

The Pt $\mathrm{L} \beta_{1}$ emission spectra were measured using a homemade Rowland-type fluorescence spectrometer set at beamline 37XU. ${ }^{28-30}$ A Johann-type spherically bent Ge(844) crystal (Saint-Gobain; curvature radius of $450 \mathrm{~mm}, d=0.57737 \AA$ ) and $\mathrm{NaI}(\mathrm{Tl})$ scintillation counter (SC; Model SP-10, Oken) were mounted. The energy resolution of the fluorescence spectrometer was estimated to be $3.4 \mathrm{eV}$ at $\mathrm{Pt} \mathrm{L} \beta_{1}$, including the contribution of the beamline. The apparent core-hole lifetime width for $\mathrm{Pt}$ $\mathrm{L} \beta_{1}$-selecting XAFS was estimated to be $2.0 \mathrm{eV}$ based on the formula $^{31}$

$$
\frac{1}{\Gamma_{\mathrm{App}}^{2}}=\frac{1}{\Gamma_{\mathrm{Pt} 3 \mathrm{~d}_{3 / 2}}{ }^{2}}+\frac{1}{\Gamma_{\mathrm{Pt} 2 \mathrm{p}_{1 / 2}}{ }^{2}}
$$

The gas for the ion chamber was $30 \% \mathrm{~N}_{2}$ and $70 \% \mathrm{He}$ in front of the sample. The slit opening in the front of the ionization chamber was $0.3 \mathrm{~mm}$ (horizontal) $\times 1.0 \mathrm{~mm}$ (vertical). The sample was placed in a plane near horizontal, tilted by $6^{\circ}$ toward the incident X-ray and by $7^{\circ}$ toward the Ge crystal. The sample surface, Ge crystal, and slit in front of the SC were controlled on a Rowland circle (radius $225 \mathrm{~mm}$ ) in the vertical plane. The openings of the receiving slit and the slit in front of the SC were $8.0 \mathrm{~mm}(\mathrm{~h}) \times 0.1 \mathrm{~mm}(\mathrm{v})$. The sample and SC were covered with a lead plate housing, except for the X-ray paths.

With the excitation energy set to $13298.8 \mathrm{eV}, \mathrm{Pt} \mathrm{L} \beta_{1}$ emission $\left(\mathrm{M}_{4} \rightarrow \mathrm{L}_{2} ; \theta_{\mathrm{B}}=75.895^{\circ}\right)$ spectra were measured. The scan step was $\sim 0.58 \mathrm{eV}$, and the accumulation time was $60 \mathrm{~s}$ for a data point. The fluorescence spectrometer was tuned to each energy around the $\mathrm{Pt} \mathrm{L} \beta_{1}$ emission peak, and $\mathrm{Pt} \mathrm{L}_{2}$-edge XANES (X-ray absorption near edge structure) spectra were measured. The scan step was $\sim 0.46 \mathrm{eV}$ with an accumulation time of 40-60 s for a data point. The $\mathrm{Pt} \mathrm{L} \beta_{1}$ fluorescence energy value was calibrated to $11070.84 \mathrm{eV}$ for the spectrum of Pt metal. ${ }^{26,27}$ The energy positions of the monochromator and the fluorescence 
spectrometer were reproduced within \pm 0.1 and $\pm 0.2 \mathrm{eV}$, respectively.

Analyses. The XAFS data were analyzed with XDAP (XAFS Services International). ${ }^{32}$ The pre-edge background was approximated by a modified Victoreen function $C_{2} / E^{2}+C_{1} / E+$ $C_{0}$. The background of the postedge oscillation was approximated by a smoothing spline function, calculated by an equation for the number of data points where $k$ was the wavenumber of photoelectrons.

$$
\sum_{i=1}^{\text {data_points }} \frac{\left(\mu x_{i}-B G_{i}\right)^{2}}{\exp \left(-0.075 k_{i}^{2}\right)} \leq \text { smoothing factor }
$$

Multiple shell curve fit analyses were performed for the Fourier-filtered $k^{3}$-weighted EXAFS data in $k$ and $R$ space using empirical amplitude and phase shift parameters extracted from EXAFS of $\mathrm{PtO}_{2}$ and $\mathrm{Pt}$ metal for $\mathrm{Pt}-\mathrm{O}$ [bond distance $R(\mathrm{Pt}-\mathrm{O})$ $=0.1993 \mathrm{~nm}$ with the coordination number $(N)$ of 6$]^{33}$ and $\mathrm{Pt}-\mathrm{Pt}$ bonds $[R(\mathrm{Pt}-\mathrm{Pt})=0.2775 \mathrm{~nm} \text { with the } N \text { of } 12]^{4}$ based on reported crystal structures. The many-body reduction factor $S_{0}{ }^{2}$ was assumed to be equal for the sample and reference. The goodness of fit was given as requested by the Committee on Standards and Criteria in X-ray Absorption Spectroscopy.

The $\mathrm{Pt}_{3_{3}-}$ and $\mathrm{L}_{2}$-edge XANES spectra were theoretically generated using ab initio calculation code FEFF $8.4,{ }^{34}$ operated in a self-consistent field and full multiple scattering modes. Theoretical calculations of Pt XANES were reported to clarify the Pt cluster size effect and spectral change upon $\mathrm{H} / \mathrm{CO}$ adsorption. ${ }^{35-37}$ The exchange -correlation potential of HedinLundqvist was chosen and corrected by adding a constant shift of $+1.0 \mathrm{eV}$ to the Fermi level. The calculated potential was also corrected by adding a constant shift of $-1.6 \mathrm{eV}$ to the "pure imaginary optical potential" to compare to $\mathrm{Pt} \mathrm{L} \beta_{1}$-selecting Pt $\mathrm{L}_{2}$-edge spectra, but no shift was given for comparison to conventional XANES. The energy of the theoretically generated spectrum was shifted by $+4.7 \mathrm{eV}$ to compare to conventional Pt $\mathrm{L}_{3 / 2}$-edge spectra and $\mathrm{Pt} \mathrm{L}_{2}$-edge spectra tuned to the $\mathrm{Pt} \mathrm{L} \beta_{1}$ peak top (11070.7-11070.8 eV). Corresponding to the $\mathrm{Pt}_{\mathrm{L}_{2}}$ edge spectra tuned to 11065.7 and $11075.4 \mathrm{eV}$, the energies of the theoretically generated spectra were shifted by 0 and +8.2 $\mathrm{eV}$, respectively.

The Pt metal site model consisted of 38 atoms of a facecentered cubic (fcc) Pt metal cuboctahedron. Among the Pt atoms, $N(\mathrm{Pt}-\mathrm{Pt})$ values of 6,8 , and 24 atoms were 12,9 , and 6 , respectively. ${ }^{38}$ The central Pt atom in the (111) surface $(N=$ 9) was considered as a representative Pt site for calculations (Figure 1) compared to an average $N$ of 7.6 for all of the $\mathrm{Pt}$ sites. A central Pt atom in the (111) surface was in vacuum or at the interface with 177 atoms of three layers of graphite $[R(\mathrm{C}-\mathrm{C})=0.1418 \mathrm{~nm}]$. The $\mathrm{Pt}-\mathrm{C}$ bond length was varied between 0.16 and $0.22 \mathrm{~nm}$ based on the crystal structures of organometallic compounds. ${ }^{39}$ Relatively long $R(\mathrm{Pt}-\mathrm{C})$ values of $0.320-0.359 \mathrm{~nm}$ were used in the calculation model of $\mathrm{Pt}_{37}$ on graphite. ${ }^{40}$ The $\mathrm{Pt}_{2}$-edge spectrum tuned to $11065.7 \mathrm{eV}$ for replica $\mathrm{Pt}-\mathrm{C} / \mathrm{Nafion}$ was best reproduced theoretically by setting the $R(\mathrm{Pt}-\mathrm{C})$ to $0.18 \mathrm{~nm}$. Thus, the nearest $\mathrm{Pt}-\mathrm{C}$ bond distance was fixed to $0.18 \mathrm{~nm}$. Average $R(\mathrm{Pt}-\mathrm{C})$ and $N$ values were $2.0 \mathrm{~nm}$ and 1.9, respectively, for seven Pt atoms at the interface (Figure 1).

\section{Results}

$\mathbf{N}_{2}$ Adsorption, XRD, TEM, and Conductivity. The specific surface area $\left(S_{\mathrm{BET}}\right)$ of $970 \mathrm{~m}^{2} \mathrm{~g}^{-1}$ for Al-MCM-41 decreased

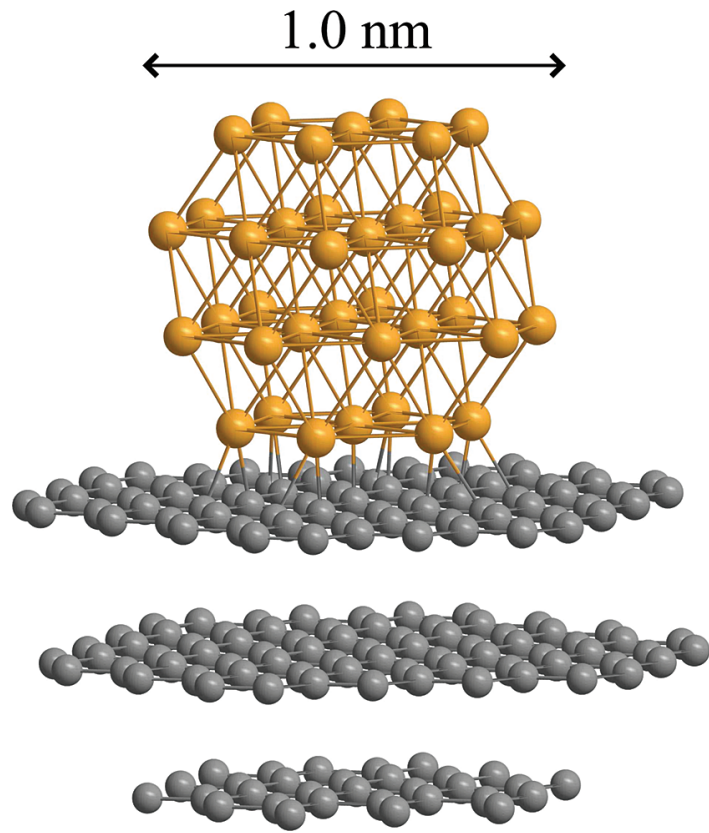

Figure 1. The $\mathrm{Pt}_{38}$ cluster model on three layers of graphite for XAFS analyses.

by $21 \%$ upon impregnation of Pt (Table 1). In contrast to this partial block of mesopores, the $S_{\mathrm{BET}}$ for Pt-Al-MCM-41 decreased by $95 \%$ after catalytic $\mathrm{C}_{2} \mathrm{H}_{2}$ decomposition, suggesting that a (nearly) complete block of mesopores by $\mathrm{C}$ formed. The loss of $S_{\mathrm{BET}}$ was recovered to $540 \mathrm{~m}^{2} \mathrm{~g}^{-1}$ with the $\mathrm{HF}$ treatment (Table 1).

The regularity of the MCM-41 framework was monitored by $\mathrm{XRD}$ during the synthesis step of replica $\mathrm{Pt}-\mathrm{C}$. The distance between the pore and neighboring pore ( $a_{0}$ of the unit cell) was $4.7 \mathrm{~nm}\left(d_{100}=4.1 \mathrm{~nm}\right)$ for Al-MCM-41 (Table 1). ${ }^{6,41}$ The value decreased to $4.5 \mathrm{~nm}\left(d_{100}=3.9 \mathrm{~nm}\right)$ upon impregnation of $\mathrm{Pt}$, in a similar trend to ref 6 . In contrast, no peak was detected in $\mathrm{XRD}$ for $\mathrm{Pt}-\mathrm{C}-\mathrm{Al}-\mathrm{MCM}-41$ probably because the electron density of $\mathrm{C}$ formed in Al-MCM-41 mesopores was similar to that of the $\mathrm{Al}-\mathrm{SiO}_{2}$ template. The lower-angle peaks recovered at $d=3.7$ and $3.2 \mathrm{~nm}$ for replica $\mathrm{Pt}-\mathrm{C}$ composites, but the intensity was weaker compared to the peak for $\mathrm{Pt}-\mathrm{Al}-\mathrm{MCM}$ 41. No distinct peaks derived from the Pt or C crystallite were observed throughout the synthesis step of replica $\mathrm{Pt}-\mathrm{C}$. After a fuel cell test for $3 \mathrm{~h}$, the replica $\mathrm{Pt}-\mathrm{C}$ composite used as the cathode was re-examined by XRD. No peak was observed in the range of $2 \theta_{\mathrm{B}}=10-75^{\circ}$, suggesting the Pt particle size remained small.

The TEM image for replica $\mathrm{Pt}-\mathrm{C}$ is depicted in Figure 2A. Darker dots of Pt particles are clearly observed between 0.38 and $3.33 \mathrm{~nm}$ (Figure 2C). The mean particle size is $1.2 \mathrm{~nm}$, with a standard deviation of $0.5 \mathrm{~nm}$. The mean size corresponds to a total of 66 atoms in one particle. ${ }^{38}$ Most of the Pt particles are within the pore size of Al-MCM-41 (2.7 nm) (Figure 2C). The replica $\mathrm{C}$ is not clear in TEM images probably because the axis of replica $\mathrm{Pt}-\mathrm{C}$ may randomly distribute, and the diameter of the rod/tube-like structure should be less than $3 \mathrm{~nm}$ dispersed over amorphous $\mathrm{C}$ coated on $\mathrm{Cu}$ mesh. However, the straight arrangement of darker Pt spots is observed, reminiscent of the ordered mesoporous structure of the Al-MCM-41 framework (Figure 2B).

The electric conductivity for Pt-Al-MCM-41 of less than 1 $\mu \mathrm{S} \mathrm{cm}^{-1}$ dramatically increased to $263 \mathrm{mS} \mathrm{cm}^{-1}$ upon catalytic $\mathrm{C}_{2} \mathrm{H}_{2}$ decomposition (Table 1). The value was by $17 \%$ superior 
TABLE 1: Physicochemical Characterization of Intermediate and Final Materials in the replica Pt-C Composite Synthesis

\begin{tabular}{|c|c|c|c|c|c|c|c|c|c|}
\hline sample & $\begin{array}{c}\text { specific } \\
S_{\mathrm{BET}} \\
\left(\mathrm{m}^{2} \mathrm{~g}^{-1}\right)\end{array}$ & $\begin{array}{l}R_{\text {Pore-Pore }} \\
(\mathrm{nm})^{a}\end{array}$ & $\begin{array}{l}\text { Pt loading } \\
(\mathrm{wt} \%)^{b}\end{array}$ & $N_{\mathrm{Pt}-\mathrm{Pt}^{c}}^{c}$ & $\begin{array}{c}N_{\mathrm{Pt}-\mathrm{O}} \text { or } \\
N_{\mathrm{Pt}-\mathrm{C}^{c}}\end{array}$ & $\mathrm{TEM}^{d}$ & $\mathrm{XRD}^{e}$ & $\begin{array}{c}\text { electric } \\
\text { conductivity } \\
\left(\mathrm{mS} \mathrm{cm}^{-1}\right)\end{array}$ & ref \\
\hline Al-MCM-41 & 970 & 4.7 & - & - & - & - & & $<0.001$ & this work \\
\hline $\mathrm{Pt}-\mathrm{C}-\mathrm{Al}-\mathrm{MCM}-41$ & 35 & n.p..$^{f}$ & 0.72 & 5.1 & 2.1 & - & n.p. $\stackrel{f}{f}^{\prime}$ & 263 & this work \\
\hline replica $\mathrm{Pt}-\mathrm{C}$ & 540 & - & 0.84 & 6.1 & 2.2 & 1.2 & n.p.,${ }^{f}$ n.p. ${ }^{f . g}$ & 259 & this work \\
\hline Pt/Vulcan XC-72 & - & - & 20 & 12 & - & - & $4.8-1$ & 224 & this work \\
\hline
\end{tabular}

${ }^{a}$ Distance from the center of the pore to the center of the neighboring pore based on XRD. ${ }^{b}$ Based on the Pt $\mathrm{L}_{3}$-edge jump value. ${ }^{c}$ Coordination number based on the Pt $\mathrm{L}_{3}$-edge EXAFS curve fit analysis. ${ }^{d}$ Average particle size of Pt based on TEM image. ${ }^{e}$ Average particle size of Pt based on XRD. ${ }^{f}$ No peak detected. ${ }^{g}$ Sample after PEFC cell test for $3 \mathrm{~h}$.
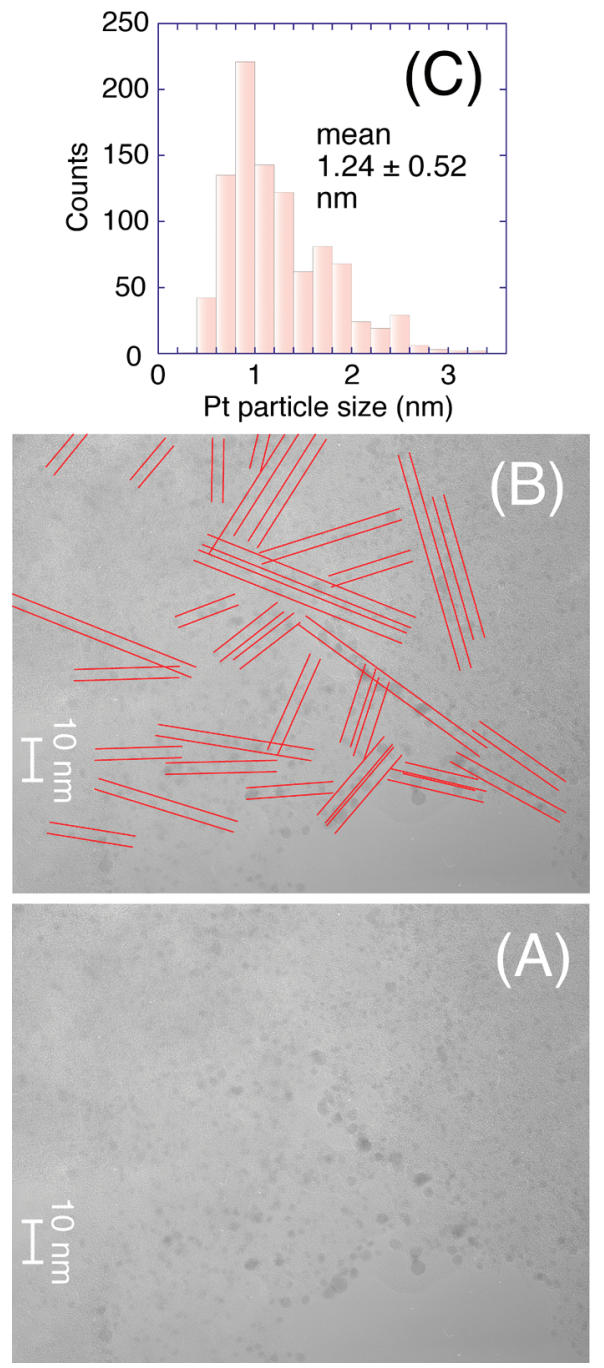

Figure 2. High-resolution TEM image for replica $\mathrm{Pt}-\mathrm{C}$ (A). The internal size of mesopores of Al-MCM-41 was added in (B). The size distribution of the darker dots of Pt particles (C).

to that for $20 \mathrm{wt} \% \mathrm{Pt} / \mathrm{Vulcan} \mathrm{XC}-72$. The value for replica $\mathrm{Pt}-\mathrm{C}\left(259 \mathrm{mS} \mathrm{cm}{ }^{-1}\right)$ was comparable to that for $\mathrm{Pt}-\mathrm{C}-\mathrm{Al}-$ MCM-41 (Table 1).

Conventional XANES. Conventional Pt $\mathrm{L}_{3}$-edge XANES spectra were measured during synthesis steps of the replica $\mathrm{Pt}-\mathrm{C}$ composite (Figure 3 ). The peak positions of XANES for Pt-Al-MCM-41 (11565.7, 11580.5, and $11594.2 \mathrm{eV}$; spectrum (a)) were similar to those for Pt metal (spectrum (e)). The intensity of three postedge peaks was weaker for Pt-Al-MCM41 compared to that for corresponding peaks for Pt metal, demonstrating that the $\mathrm{Pt}$ particles in $\mathrm{Pt}-\mathrm{Al}-\mathrm{MCM}-41$ were on the nanometer scale.

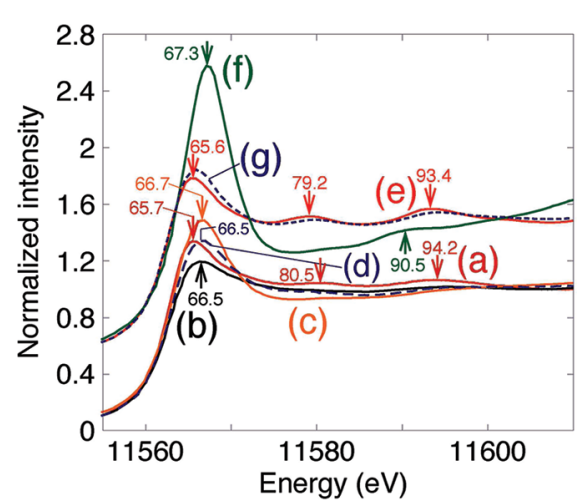

Figure 3. Normalized $\mathrm{Pt}_{3}$-edge XANES spectra for Pt-Al-MCM41 (a), $\mathrm{Pt}-\mathrm{C}-\mathrm{Al}-\mathrm{MCM}-41$ (b), replica $\mathrm{Pt}-\mathrm{C}$ in air (c), replica $\mathrm{Pt}-\mathrm{C} /$ Nafion in air (d), Pt metal of $5 \mu \mathrm{m}$ thickness (e), $\mathrm{PtO}_{2}$ (f), and $20 \mathrm{wt}$ $\% \mathrm{Pt} /$ Vulcan XC-72/Nafion (g).

The peak at $11566.5 \mathrm{eV}$ for $\mathrm{Pt}-\mathrm{C}-\mathrm{Al}-\mathrm{MCM}-41$ (spectrum (b)) became weaker and broader compared to that at 11565.7 $\mathrm{eV}$ in spectrum (a). An attempt was made to fit spectra (a) and (b) with theoretical spectra for a metallic Pt site or interface Pt site between the metal and graphite. It was difficult to fit because spectrum (a) seemed to be a mixture of metallic and oxidic Pt sites. Spectrum (b) seemed to be a mixture of metallic Pt and $\mathrm{Pt}$ at the interface with $\mathrm{C}$. Instead, $\mathrm{Pt} \mathrm{L} \beta_{1}$-selecting XANES spectra were compared to theoretical data because the Pt state was selected and the spectral pattern was sharpened. ${ }^{28,29,42-47}$

The XANES spectrum for the replica $\mathrm{Pt}-\mathrm{C}$ composite in air is shown in Figure 3c. The energy of first peak above the absorption edge $(11566.7 \mathrm{eV})$ is intermediate between the peak at $11565.6 \mathrm{eV}$ for the Pt metal (spectrum (e)) and the one at $11567.3 \mathrm{eV}$ for $\mathrm{PtO}_{2}$ (spectrum (f)). The first peak for spectrum (c) is more intense (1.47) than those for spectra (a) and (b) (1.33-1.19), and the postedge pattern of spectrum (c) became featureless. Thus, oxidation of part of metallic $\mathrm{Pt}$ in $\mathrm{Pt}-\mathrm{C}-\mathrm{Al}-$ MCM-41 was suggested after the removal of the Al-MCM-41 framework. In the XANES spectrum for Pt sites in replica $\mathrm{Pt}-\mathrm{C}$ / Nafion in air (Figure 3d), the first peak above the absorption edge shifted down to $11566.5 \mathrm{eV}$, and the intensity decreased (1.34). The peak intensity was essentially identical to that for spectrum (a) (1.34 versus 1.33). No peak feature at $11590.5 \mathrm{eV}$ for $\mathrm{PtO}_{2}$ (spectrum (f)) was detected in spectrum (d). The postedge pattern of spectrum (d) was most like that of spectrum (b).

In comparison, a XANES pattern of 20 wt \% Pt/Vulcan XC72/Nafion (Figure $3 \mathrm{~g}$ ) corresponded exactly to that for Pt metal (spectrum (e)). The mean Pt particle size in the sample was 4.8 $\mathrm{nm}$ based on the peak width of XRD, much greater than that in the replica $\mathrm{Pt}-\mathrm{C}$ composite $(1.2 \mathrm{~nm})$ and in less contact with Nafion. 


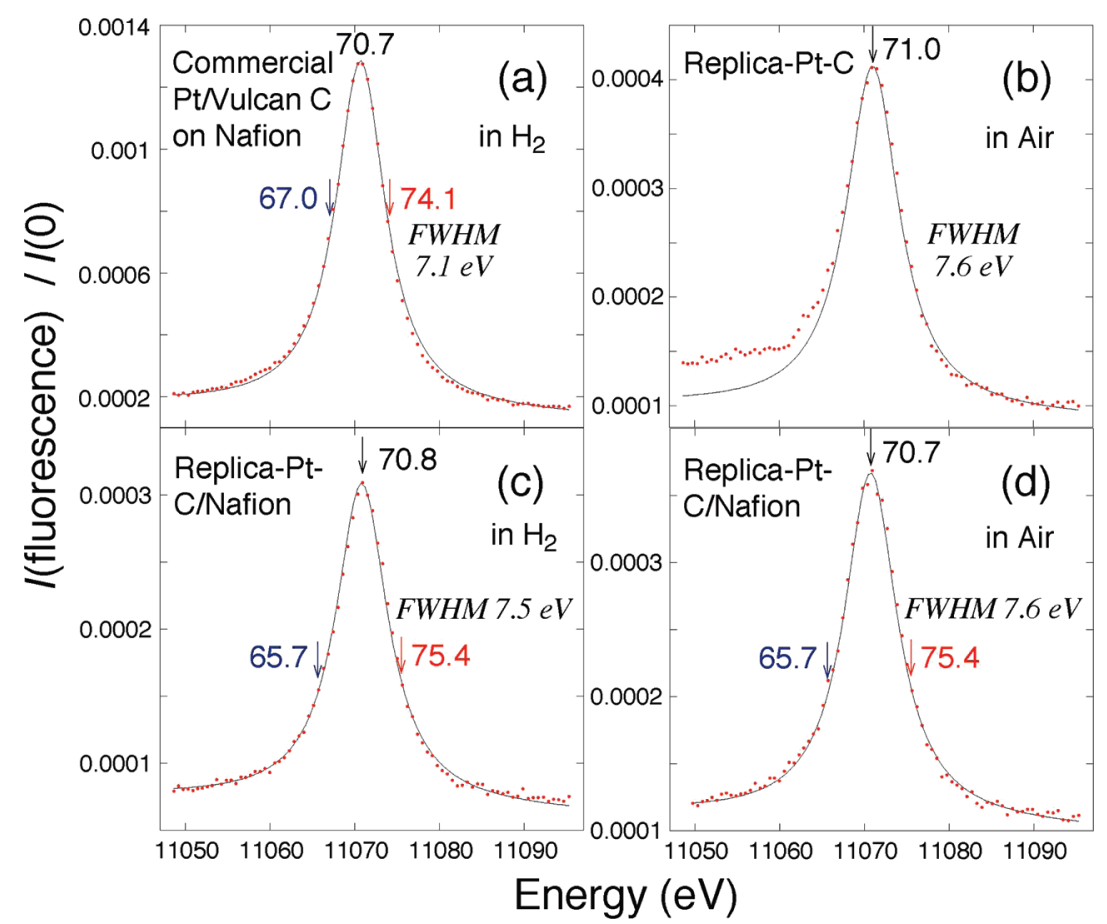

Figure 4. $\mathrm{Pt} \mathrm{L} \beta_{1}$ emission spectra for $\mathrm{Pt} /$ Vulcan $\mathrm{XC}-72 / \mathrm{Nafion}$ in $\mathrm{H}_{2}$ (a), replica $\mathrm{Pt}-\mathrm{C}$ in air (b), replica $\mathrm{Pt}-\mathrm{C} / \mathrm{Nafion}$ in $\mathrm{H}_{2}$ (c), and replica $\mathrm{Pt}-\mathrm{C} /$ Nafion in air (d). The arrows indicate tune energy values for $\mathrm{Pt} \mathrm{L} \beta_{1}$-selecting XAFS measurements (Figure 5).

X-ray Emission and State-Selective XANES. The Pt $\mathrm{L} \beta_{1}$ emission peaks for replica $\mathrm{Pt}-\mathrm{C} / \mathrm{Nafion}$ in $\mathrm{H}_{2}$ or in air appeared at $11070.7-11070.8 \mathrm{eV}$ (Figure 4c, d), essentially identical to that for Pt metal $(11070.84 \mathrm{eV})$. The emission peak for replica $\mathrm{Pt}-\mathrm{C}$ powder in air was $11071.0 \mathrm{eV}$ (spectrum (b)), shifted by $+0.2 \mathrm{eV}$ from that for Pt metal. The fwhm (full width at halfmaximum) values were relatively greater $(7.5-7.6 \mathrm{eV})$ for replica $\mathrm{Pt}-\mathrm{C} / \mathrm{Nafion}$ and replica $\mathrm{Pt}-\mathrm{C}$ powder compared to 7.1-7.2 eV for standard Pt compounds and $20 \mathrm{wt} \% \mathrm{Pt} / \mathrm{Vulcan}$ XC-72/Nafion (spectrum (a)).

Then, $\mathrm{Pt} \mathrm{L}_{2}$-edge XANES spectra were measured (Figure 5B) tuned to the $\mathrm{Pt} \mathrm{L} \beta_{1}$ peak top $(11070.7-11071.0 \mathrm{eV}$; the arrows in Figure 4). The absorption edge position progressively shifted from $13272.3 \mathrm{eV}$ for Pt metal (spectrum (a)) to $13272.8 \mathrm{eV}$ for replica $\mathrm{Pt}-\mathrm{C} / \mathrm{Nafion}$ in $\mathrm{H}_{2}$ (spectrum (f)), $13272.9 \mathrm{eV}$ for replica $\mathrm{Pt}-\mathrm{C} /$ Nafion in air (spectrum (e)), or $13273.4 \mathrm{eV}$ for replica $\mathrm{Pt}-\mathrm{C}$ in air (spectrum (d)) and then to $13274.2 \mathrm{eV}\left(\mathrm{PtO}_{2}\right.$, spectrum (b)). Despite the gradual edge shift, postedge peaks appeared at almost the same position (13287-13289, 13302, 13312 , and $13327 \mathrm{eV}$ ) for replica $\mathrm{Pt}-\mathrm{C} / \mathrm{Nafion}$ in $\mathrm{H}_{2} /$ in air and replica $\mathrm{Pt}-\mathrm{C}$ in air (spectra (d)-(f)) as those for Pt metal (spectrum (a)). Thus, metallic Pt states were selected in replica $\mathrm{Pt}-\mathrm{C}$ samples (as powder or on Nafion) in XANES spectra tuned to $11070.7-11071.0 \mathrm{eV}$.

$\mathrm{Pt}_{\mathrm{L}}$-edge XANES spectra tuned to the lower-energy side of $\mathrm{Pt} \mathrm{L} \beta_{1}$ peaks (11065.7-11067.0 eV; the arrows in Figure 4) are shown in Figure 5A. The first intense peak at 13272.3-13273.3 $\mathrm{eV}$ above the absorption edge (spectra A(e), (f)) became weaker compared to the peaks in spectra tuned to the $\mathrm{Pt} L \beta_{1}$ peak top (panel B(e), (f)). The absorption edge position for replica $\mathrm{Pt}-\mathrm{C} /$ Nafion shifted from $13267.9 \mathrm{eV}$ in $\mathrm{H}_{2}$ to $13268.1 \mathrm{eV}$ in air.

The postedge pattern for $20 \mathrm{wt} \% \mathrm{Pt} / \mathrm{Vulcan} \mathrm{XC}-72 / \mathrm{Nafion}$ (Figure $5 \mathrm{~A}(\mathrm{c})$ ) resembled that of metallic $\mathrm{Pt}$ tuned to the $\mathrm{Pt}$ $\mathrm{L} \beta_{1}$ peak top (Figure $5 \mathrm{~B}(\mathrm{a})$ ) if the spectrum $\mathrm{B}$ (a) shifted by 2.3 $\mathrm{eV}$ toward the lower-energy side. In contrast, the postedge pattern of spectra $\mathrm{A}(\mathrm{e})$ and (f) for replica $\mathrm{Pt}-\mathrm{C} / \mathrm{Nafion}$ became featureless in panel $\mathrm{A}$ and did not resemble that of metallic $\mathrm{Pt}$ or $\mathrm{PtO}_{2}$. The spectra (e) and (f) resembled theoretical spectra for the interface $\mathrm{Pt}$ atom between $\mathrm{Pt}$ metal and graphite (Figures 1 and $5 \mathrm{~A}(\mathrm{~h})$ ) when the energy was shifted by $-4.7 \mathrm{eV}$ relative to XANES tuned to the $\mathrm{Pt} \mathrm{L} \beta_{1}$ peak top.

Next, $\mathrm{Pt} \mathrm{L}_{2}$-edge XANES spectra tuned to the higher-energy side of $\mathrm{Pt} \mathrm{L} \beta_{1}$ peaks (11074.1-11075.4 eV; the arrows in Figure 4) were measured for replica $\mathrm{Pt}-\mathrm{C} / \mathrm{Nafion}$ compared to $20 \mathrm{wt}$ $\% \mathrm{Pt} /$ Vulcan XC-72/Nafion (Figure 5C). The postedge pattern for spectra $\mathrm{C}(\mathrm{e})$ and (f) in Figure 5 resembled that of corresponding spectra tuned to the $\mathrm{Pt} \mathrm{L} \beta_{1}$ peak top (Figure $5 \mathrm{~B}(\mathrm{e}$ ), (f)) if the spectra $\mathrm{B}(\mathrm{e})$ and (f) shifted by $3.5 \mathrm{eV}$ toward the higher-energy side. The spectra (e) and (f) resembled theoretical spectra for a Pt atom in a Pt nanoparticle (Figure $5 \mathrm{C}(\mathrm{g})$ ) when the energy was shifted by $+3.5 \mathrm{eV}$ relative to XANES tuned to the $\mathrm{Pt} \mathrm{L} \beta_{1}$ peak top (Figure $5 \mathrm{~B}(\mathrm{~g})$ ). The absorption edge position for replica $\mathrm{Pt}-\mathrm{C} / \mathrm{Nafion}$ in air $(13276.4 \mathrm{eV})$ was by $1.0 \mathrm{eV}$ greater than that in $\mathrm{H}_{2}$. Postedge peak shifts were within $1 \mathrm{eV}$ toward the higher-energy side by switching the ambient gas from $\mathrm{H}_{2}$ (spectrum (f)) to air (spectrum (e)).

The postedge pattern for $20 \mathrm{wt} \% \mathrm{Pt} / \mathrm{Vulcan} \mathrm{XC}-72 / \mathrm{Nafion}$ (Figure $5 \mathrm{C}(\mathrm{c})$ ) resembled that of metallic $\mathrm{Pt}$ tuned to the $\mathrm{Pt}$ $\mathrm{L} \beta_{1}$ peak top (Figure $5 \mathrm{~B}(\mathrm{a})$ ) if the spectrum $\mathrm{B}(\mathrm{a})$ shifted by 2.7 $\mathrm{eV}$ toward the higher-energy side. The $\mathrm{Pt} \mathrm{L} \beta_{1}$ tune energy for spectrum $\mathrm{C}(\mathrm{c})$ was greater by $3.4 \mathrm{eV}$ compared to the peak top. The Pt $\mathrm{L} \beta_{1}$ tune energy for spectrum A(c) was smaller by 3.7 $\mathrm{eV}$ compared to the peak top, and the XANES peaks shift was $2.3 \mathrm{eV}$. The reduction of the tune energy difference versus the XAFS energy difference was $62-80 \%$ mainly due to the finalstate relaxation effect. ${ }^{48}$

\section{Discussion}

Replica Pt $-\mathbf{C}$ Morphology. The Pt loading in Pt-Al-MCM41 was 1.3 wt \% after cation exchange and reduction in $\mathrm{H}_{2}$ at $573 \mathrm{~K}$ (Table 1). The amount corresponds to $67.5 \mu \mathrm{mol}$ of $\mathrm{Pt}$ substituting on the proton sites for $1 \mathrm{~g}$ of Al-MCM-41 (412 $\mu \mathrm{mol}$ of $\mathrm{Al} \mathrm{g}^{-1}$ ). Therefore, $32.8 \%$ (or 16.4\%) of the proton 


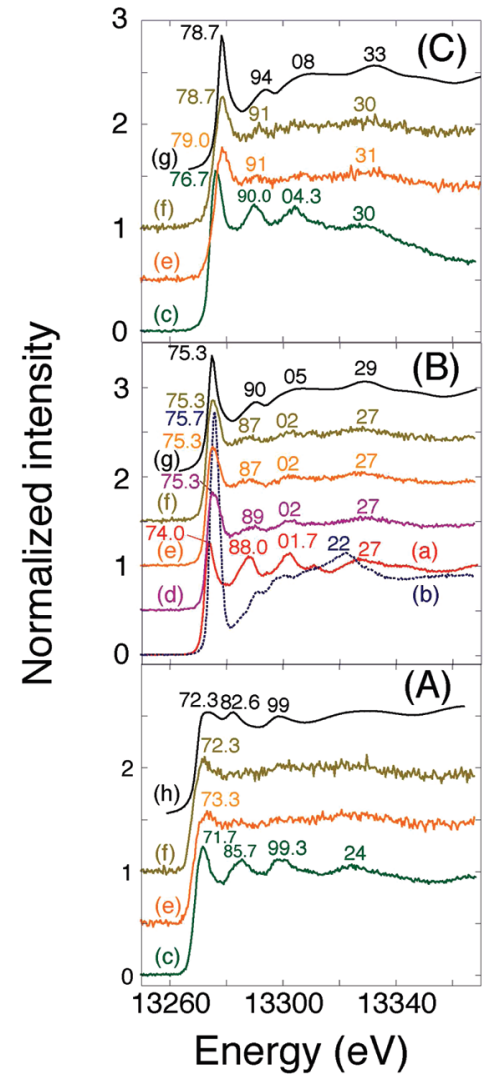

Figure 5. Normalized $\mathrm{Pt}_{\mathrm{L}_{2}}$-edge $\mathrm{XANES}$ spectra for $\mathrm{Pt}$ metal (a), $\mathrm{PtO}_{2}$ (b), 20 wt \% Pt/Vulcan XC-72/Nafion in $\mathrm{H}_{2}$ (c), replica Pt-C in air (d), replica Pt-C/Nafion in air (e), and replica Pt-C/Nafion in $\mathrm{H}_{2}$ (f). The tune energy was $11067.0 \mathrm{eV}$ (c) and $11065.7 \mathrm{eV}(\mathrm{e}, \mathrm{f})$ in panel A, $11070.8 \mathrm{eV}$ (a), $11070.6 \mathrm{eV}$ (b), $11071.0 \mathrm{eV}$ (d), $11070.7 \mathrm{eV}$ (e), and $11070.8 \mathrm{eV}$ (f) in panel B, and $11074.1 \mathrm{eV}(\mathrm{c})$ and $11075.4 \mathrm{eV}(\mathrm{e}$, f) in panel $\mathrm{C}$ (see the arrows in Figure 4). Theoretically generated Pt $\mathrm{L}_{2}$-edge XANES spectrum for a central Pt atom in the (111) face of a cuboctahedral $\mathrm{Pt}_{38}$ cluster $(\mathrm{g})$ and the atom in contact with graphite layers $[R(\mathrm{Pt}-\mathrm{C})=0.18 \mathrm{~nm}, R(\mathrm{C}-\mathrm{C})=0.1418 \mathrm{~nm}](\mathrm{h})$. The energy shifts were $0,4.7$, and $8.2 \mathrm{eV}$ for spectrum $\mathrm{A}(\mathrm{h}), \mathrm{B}(\mathrm{g})$, and $\mathrm{C}(\mathrm{g})$, respectively.

sites of Al-MCM-41 were exchanged to $\left[\mathrm{Pt}\left(\mathrm{NH}_{3}\right)_{4}\right]^{2+}$ species (or $\left[\mathrm{Pt}\left(\mathrm{NH}_{3}\right)_{4}(\mathrm{OH})\right]^{+}$species). This exchange ratio was greater than values for Pt zeolites, ${ }^{4}{ }^{9}$ but the Pt amounts introduced into the samples were similar between 0.6 and $2.0 \mathrm{wt} \%$ due to the difference of $\mathrm{Al}$ concentrations, $10-12 \mathrm{wt} \%$ for zeolites ${ }^{49}$ versus $1.11 \mathrm{wt} \%$ for $\mathrm{Al}-\mathrm{MCM}-41$ of this work.

The Pt loading for $\mathrm{Pt}-\mathrm{C}-\mathrm{Al}-\mathrm{MCM}-41$ was $0.72 \mathrm{wt} \%$ after catalytic $\mathrm{C}_{2} \mathrm{H}_{2}$ decomposition at $973 \mathrm{~K}$ over $\mathrm{Pt}$ particles in $\mathrm{Al}-$ MCM-41 (Table 1). Therefore, the $\mathrm{C}$ content in the $\mathrm{Pt}-\mathrm{C}-\mathrm{Al}-$ MCM-41 was $44.6 \%$. If the pore volume for Al-MCM-41 was $0.6 \mathrm{~cm}^{3} \mathrm{~g}^{-1,41}$ the density of formed $\mathrm{C}$ was $2.25 \mathrm{~g} \mathrm{~cm}^{-3}$ (graphite), and catalytically formed $\mathrm{C}$ remained exclusively inside of the mesopores of Al-MCM-41 (HR-TEM), it is estimated that $60.5 \%$ of the mesopores was stuffed. No C rod/ tube pushed out of mesopores was detected in TEM images for $\mathrm{Pt}-\mathrm{C}-\mathrm{Al}-\mathrm{MCM}-41$ (not shown). The $S_{\mathrm{BET}}$ value for $\mathrm{Pt}-\mathrm{Al}-$ MCM-41 $\left(767 \mathrm{~m}^{2} \mathrm{~g}^{-1}\right)$ decreased by $95 \%$ after catalytic $\mathrm{C}_{2} \mathrm{H}_{2}$ decomposition (Table 1), supporting the effective block of mesopores. Only the external surface of Al-MCM-41 adsorbed $\mathrm{N}_{2}$.

The Pt loading for replica $\mathrm{Pt}-\mathrm{C}$ was 0.84 wt $\%$ after the removal of the Al-MCM-41 framework (Table 1). Therefore, $47.4 \%$ of $\mathrm{Pt}$ in $\mathrm{Pt}-\mathrm{C}-\mathrm{Al}-\mathrm{MCM}-41$ was lost during the washing with $\mathrm{HF}$ solution. The specific $S_{\mathrm{BET}}$ value for replica $\mathrm{Pt}-\mathrm{C}$ recovered as much as $540 \mathrm{~m}^{2} \mathrm{~g}^{-1}$ (Table 1). When the catalytic $\mathrm{C}_{2} \mathrm{H}_{2}$ decomposition temperature was $1073 \mathrm{~K}$, thermally decomposed $\mathrm{C}$ was formed as a byproduct but could be separated from $\mathrm{Pt}-\mathrm{C}-\mathrm{Al}-\mathrm{MCM}-41$. The $\mathrm{C}$ content in the $\mathrm{Pt}-\mathrm{C}-\mathrm{Al}-$ MCM-41 was $66.0 \%$. It is estimated that $143.9 \%$ of the mesopores for Al-MCM-41 were stuffed, suggesting excessive C was pushed out of mesopores. At $873 \mathrm{~K}$, acetylene did not react either catalytically or thermally, consistent with ref 6 .

When catalytic $\mathrm{C}_{2} \mathrm{H}_{2}$ decomposition was performed at 973 $\mathrm{K}$ in a closed circulation system or in a batch for Pt-Al-MCM41 , the decomposition was by $75 \%$ slower than that in the flow setup in this study. Formed $\mathrm{H}_{2}$ due to $\mathrm{C}_{2} \mathrm{H}_{2}$ decomposition remained in the system and inhibited further $\mathrm{C}_{2} \mathrm{H}_{2}$ decomposition due to equilibrium. When MCM-41 or FSM-16 was used instead of Al-MCM-41, ion exchange was not applicable to introduce Pt species. Catalytic $\mathrm{C}_{2} \mathrm{H}_{2}$ decomposition was performed on the Pt nanoparticles, followed by HF treatment. The Pt content in obtained replica $\mathrm{Pt}-\mathrm{C}$ was only 0.09 wt $\%$.

The mean Pt particle size was $1.2 \mathrm{~nm}$ for replica Pt $-\mathrm{C}$ (Figure 2A, C). The average $N$ value for $\mathrm{Pt}-\mathrm{Pt}$ bonds by EXAFS (6.1; Table 1) suggested even smaller Pt nanoparticles. ${ }^{38}$ This discrepancy is due to the contribution of $N_{\mathrm{Pt}-\mathrm{O}}$ or $N_{\mathrm{Pt}-\mathrm{C}}$. $\mathrm{Pt}-\mathrm{C}-\mathrm{Al}-\mathrm{MCM}-41$ and replica $\mathrm{Pt}-\mathrm{C}$ samples both measured in air provided $N_{\mathrm{Pt}-\mathrm{O}}$ values of $2.1-2.2$, including the undividable contribution of $N_{\mathrm{Pt}-\mathrm{C}}$ (Table 1) because the exterior of these Pt nanoparticles should be oxidized and/or carburized.

Pt Sites in Replica Pt-C. Partial oxidation of Pt sites was demonstrated in conventional Pt XANES for a replica $\mathrm{Pt}-\mathrm{C}$ composite (Figure 3c). In contrast, a high energy resolution $\mathrm{Pt}$ $\mathrm{L}_{2}$-edge XANES spectrum (Figure $5 \mathrm{~B}(\mathrm{~d})$ ) tuned to the $\mathrm{Pt} \mathrm{L} \beta_{1}$ peak top (11071.0 eV; Figure 4b) preferably selected metallic Pt. The emission of Pt(IV) sites appeared at $11070.6 \mathrm{eV}$ (not shown), and the spectral pattern tuned to $11070.6 \mathrm{eV}$ for $\mathrm{PtO}_{2}$ (Figure $5 \mathrm{~B}(\mathrm{~b})$ ) was totally different from that in spectrum (d).

Conventional XANES for replica Pt-C/Nafion (Figure 3d) was similar to that for Pt metal (spectrum (e)) in the absorption edge region or that for $\mathrm{Pt}-\mathrm{C}-\mathrm{Al}-\mathrm{MCM}-41$ (spectrum (b)) in the postedge region. The XANES spectra tuned to the $\mathrm{Pt} L \beta_{1}$ peak top for replica $\mathrm{Pt}-\mathrm{C} / \mathrm{Nafion}$ both in air and in $\mathrm{H}_{2}$ exclusively detected metallic Pt sites (Figure 5B(e), (f)). The spectra resembled well theoretical spectrum $\mathrm{B}(\mathrm{g})$ generated for the surface Pt site on the (111) face of a cuboctahedral $\mathrm{Pt}_{38}$ cluster.

When the tune energy was on the lower energy side of the $\mathrm{Pt} \mathrm{L} \beta_{1}$ peak for replica $\mathrm{Pt}-\mathrm{C} / \mathrm{Nafion}$ (Figure $4 \mathrm{c}, \mathrm{d}$ ), the first intense peak at $13272.3-13273.3 \mathrm{eV}$ became weaker (Figure $5 \mathrm{~A}(\mathrm{e})$, (f)), suggesting greater occupation of the Pt $5 \mathrm{~d}$ band. The spectra (e) and (f) resembled well theoretical spectrum $5 \mathrm{~A}(\mathrm{~h})$ calculated for the interface site between the Pt nanoparticle and graphite layers (Figure 1). Thus, interface Pt sites were predominantly selected in $\mathrm{Pt}_{2}$-edge XANES tuned to 11065.7 $\mathrm{eV}$ for replica $\mathrm{Pt}-\mathrm{C} / \mathrm{Nafion}$, and negative charge transfer from $\mathrm{C}$ to Pt nanoparticles was suggested. However, the selective detection of interface Pt sites was unsuccessful for Pt(mean size $4.8 \mathrm{~nm}$, Table 1)/Vulcan XC-72/Nafion. Only dominant metallic Pt sites appeared in XANES tuned to $11067.0 \mathrm{eV}$.

EXAFS, in general, provides statistical bonding information for $\mathrm{Pt}$ in a sample irradiated with $\mathrm{X}$-ray. Therefore, $\mathrm{Pt}-\mathrm{C}$ bonds are statistically preferably detectable for the Pt sites in $\mathrm{Pt}$ particles in a narrow size distribution centered at $1.2 \mathrm{~nm}$ compared to Pt sites in Pt particles of mean size $4.8 \mathrm{~nm}$. Even so, the contribution of $\mathrm{Pt}-\mathrm{C}$ bonds was statistically minor for replica $\mathrm{Pt}-\mathrm{C}$ compared to that of $\mathrm{Pt}-\mathrm{Pt}$ bonds (Figure $3 \mathrm{a}, \mathrm{b}$ ). High energy resolution XAFS in this work still provides 
statistical bonding information; however, the information is specific for $\mathrm{Pt}$ sites corresponding to a lower $\mathrm{Pt} \mathrm{L} \beta_{1}$ emission energy of $11065.7 \mathrm{eV}$ for replica $\mathrm{Pt}-\mathrm{C} / \mathrm{Nafion}$ (Figure $5 \mathrm{~A}(\mathrm{e})$, (f)) and Pt/Vulcan XC-72/Nafion (Figure 5A(c)). Thus, the discussion is reasonable that $\mathrm{Pt}$ sites in contact with $\mathrm{C}$ were discriminated among smaller $\mathrm{Pt}$ particles in replica $\mathrm{Pt}-\mathrm{C} / \mathrm{Nafion}$, and the XANES spectrum was compared to theoretical XANES data (Figure $5 \mathrm{~A}(\mathrm{~h})$ ) for the interface $\mathrm{Pt}$ sites depicted in Figure 1. Even after being tuned to a lower $\mathrm{Pt} \mathrm{L} \beta_{1}$ energy of 11067.0 $\mathrm{eV}$, the $\mathrm{Pt}-\mathrm{C}$ interface site was not discriminated for Pt/Vulcan $\mathrm{XC}-72 /$ Nafion because the site population was too small among $\mathrm{Pt}$ sites corresponding to lower $\mathrm{Pt} \mathrm{L} \beta_{1}$ emission energy. It is apparent that the reason was the greater mean Pt particle size and predominant population of $\mathrm{Pt}-\mathrm{Pt}$ bonds in $\mathrm{Pt} / \mathrm{Vulcan} \mathrm{XC}$ 72/Nafion.

The XANES spectra tuned on the higher-energy side of $\mathrm{Pt}$ $\mathrm{L} \beta_{1}$ (Figure $4 \mathrm{c}$, d) for replica $\mathrm{Pt}-\mathrm{C} / \mathrm{Nafion}$ resembled the theoretical spectrum in Figure $5 \mathrm{C}(\mathrm{g})$ generated for surface the $\mathrm{Pt}$ site on the (111) face of $\mathrm{Pt}_{38}$, shifted by $+3.5 \mathrm{eV}$ from spectrum $\mathrm{B}(\mathrm{g})$. This XANES shift was rationalized based on the difference of the fluorescence tune energy and the finalstate relaxation effect. Metallic Pt state was selected in the XANES tuned to $11075.4 \mathrm{eV}$.

Due to the selection rule of the electronic transition (azimuthal quantum number $\Delta l= \pm 1$; total angular momentum $\Delta j=0$, $\pm 1)$, the near-edge transition from $\mathrm{L}_{2}\left({ }^{2} \mathrm{P}_{1 / 2}\right)$ is limited to $\mathrm{O}_{4}$ $\left({ }^{2} \mathrm{D}_{3 / 2}\right)$ at a deeper energy than $\mathrm{O}_{5}\left({ }^{2} \mathrm{D}_{5 / 2}\right)$, whereas those from $\mathrm{L}_{3}\left({ }^{2} \mathrm{P}_{3 / 2}\right)$ are both limited to $\mathrm{O}_{4}$ and $\mathrm{O}_{5}$. ${ }^{49}$ This is the reason why the $\mathrm{Pt}_{2}$-edge white line is weaker than that in $\mathrm{Pt} \mathrm{L}_{3}$-edge spectra. ${ }^{35}$ By changing the fluorescence tune energy between 11065.7 and $11075.4 \mathrm{eV}$ (Figure 4c, d), electron-sufficient Pt sites in contact with $\mathrm{C}$ (Figure $5 \mathrm{~A}(\mathrm{e})$, (f)) and relatively electron deficient $\mathrm{Pt}$ sites on/in Pt nanoparticles (Figure 5B, C(e), (f)) were discriminated, respectively. In contrast, a negligible difference was detected by switching the ambient gas from $\mathrm{H}_{2}$ to air for replica $\mathrm{Pt}-\mathrm{C} / \mathrm{Nafion}$, except for an absorption edge shift less of than $1 \mathrm{eV}$ (Figure 5e, f). The shape resonance peak near the $\mathrm{L}_{3}$-edge was reported, for example, by $\mathrm{H}$ adsorption on $\mathrm{Pt} .{ }^{35,36,49}$ One of the possibilities is that the antibonding level between $\mathrm{Pt} 5 \mathrm{~d}_{3 / 2}$ and the frontier level of the adsorbent was occupied for replica $\mathrm{Pt}-\mathrm{C} / \mathrm{Nafion}$ samples. It is also possible that a similar shape resonance peak appeared due to adsorbed $\mathrm{H}$ in $\mathrm{H}_{2}$ and adsorbed $\mathrm{O}_{2}$ in air. A technical reason may be that the XAFS measurements for Pt catalysts on Nafion were done as in a half-cell and no water was supplied/catalytically produced in samples during the measurements. The contact of $\mathrm{Pt}$ with $\mathrm{C}$ (solid) and Nafion(liquid) was found to be secure; however, Nafion in pure $\mathrm{H}_{2}$ or air was not entirely mobile and thus may block the Pt/gas interface sites.

Implications to the PEFC Cathode Catalyst of Replica Pt-C. The electric conductivity for $\mathrm{Pt}-\mathrm{C}-\mathrm{Al}-\mathrm{MCM}-41$ was by $17 \%$ superior to that for conventional $20 \mathrm{wt} \% \mathrm{Pt} / \mathrm{Vulcan}$ $\mathrm{XC}-72$ (Table 1) probably because catalytically formed $\mathrm{C}$ in mesopores was regularly oriented in the [001] direction of AlMCM-41, despite the low $\mathrm{Pt}$ content in $\mathrm{Pt}-\mathrm{C}-\mathrm{Al}-\mathrm{MCM}-41$ $(0.72 \mathrm{wt} \%)$. The comparable conductivity values for $\mathrm{Pt}-\mathrm{C}-\mathrm{Al}-$ MCM-41 and replica $\mathrm{Pt}-\mathrm{C}$ (Table 1) were also understandable if we think that the nonconducting Al-MCM-41 part was removed, but regular orientation of the $\mathrm{C}$ rod/tube would be lost for the latter.

To enable $0.13 \mathrm{mg} \mathrm{Pt} \mathrm{cm}^{-2}$ as the cathode catalyst, $76 \mathrm{mg}$ of replica $\mathrm{Pt}-\mathrm{C}(0.84 \mathrm{wt} \% \mathrm{Pt})$ was mounted on $\mathrm{C}$ paper versus $25 \mathrm{mg}$ of $20 \mathrm{wt} \% \mathrm{Pt} / \mathrm{Vulcan} \mathrm{XC}-72$ on $\mathrm{C}$ paper $\left(1 \mathrm{mg} \mathrm{Pt} \mathrm{cm}{ }^{-2}\right)$ (see Supporting Information). The greater amount of replica
$\mathrm{Pt}-\mathrm{C}$ mounted caused difficulty in making physical contact of Pt with the electrolyte (wet polymer to transport protons) and oxygen gas at the same time. ${ }^{1}$ Hence, to enable practical electric power generation using replica $\mathrm{Pt}-\mathrm{C}$ catalyst, the $\mathrm{Pt}$ content in replica $\mathrm{Pt}-\mathrm{C}$ powder should be increased to $20 \mathrm{wt} \% \mathrm{Pt}$ typical for other commercial $\mathrm{Pt} / \mathrm{C}$ catalysts while keeping the $\mathrm{Pt}$ particle size of $1.2 \mathrm{~nm}$. One possibility is to increase the $\mathrm{Al}$ content from $1.11 \mathrm{wt} \%$ to the zeolite level of $10-12 \mathrm{wt} \%$ to augment the cationic Pt complexes exchanged. Another possibility is to utilize a three-dimensional mesoporous template, for example, MCM-48, to stabilize Pt nanoparticles on/in formed $\mathrm{C}$ in the three-dimensional mesopores. The advantage to synthesize metal particles in a narrow size distribution centered at $\sim 1 \mathrm{~nm}$ and to secure contact of the metal and $\mathrm{C}$ demonstrated in this paper can be applied to nonprecious metal-C catalysts, for example, cobalt or iron porphyrin decomposition ${ }^{50}$ in mesoporous $\mathrm{SiO}_{2-}$ based templates. Carbonization of block copolymer selfassembled with $\mathrm{Pt}, \mathrm{Pb}$, and $\mathrm{Nb}$ species is another possibility to produce a $\mathrm{Pt}-\mathrm{C}$ composite, as recently reported for an anode material resistive to $\mathrm{CO}$ poisoning. ${ }^{51}$

\section{Conclusions}

Pt nanoparticles introduced by cation group exchange and formed by heating in vacuum at $573 \mathrm{~K}$ inside of Al-MCM-41 catalyzed $\mathrm{C}_{2} \mathrm{H}_{2}$ decomposition to form a $\mathrm{C}$ rod/tube. The AlMCM-41 template was removed with a $15 \%$ HF solution. $\mathrm{Pt}$ nanoparticles with a mean size of $1.2 \mathrm{~nm}$ were obtained embedded on/in the $\mathrm{C}$ matrix. The Pt loading was 0.84 wt \%. The replica $\mathrm{Pt}-\mathrm{C}$ synthesis procedure was supported by the changes of the specific $S_{\mathrm{BET}}$ value from $767 \mathrm{~m}^{2} \mathrm{~g}^{-1}$ for $\mathrm{Pt}-\mathrm{Al}-$ MCM-41 to $35 \mathrm{~m}^{2} \mathrm{~g}^{-1}$ for Pt-C-Al-MCM-41 and then to 540 $\mathrm{m}^{2} \mathrm{~g}^{-1}$ for replica $\mathrm{Pt}-\mathrm{C}$. The Pt particles could not be monitored by XRD both before and after cathode catalytic tests in PEFC, suggesting the stability of $1.2 \mathrm{~nm}$ Pt particles embedded on/in the $\mathrm{C}$ matrix. The $\mathrm{Pt}$ sites in replica $\mathrm{Pt}-\mathrm{C}$ pressed to Nafion were analyzed by $\mathrm{Pt} \mathrm{L} \beta_{1}$-selecting high energy resolution $\mathrm{Pt}$ $\mathrm{L}_{2}$-edge XANES spectra. The first peak above the absorption edge for the spectra tuned to $11065.7 \mathrm{eV}$ was weak, suggesting that interface $\mathrm{Pt}$ site received electron transfer from the $\mathrm{C}$ in contact. The high energy resolution XANES spectra for both interfacial Pt with $\mathrm{C}$ and metallic Pt sites were nicely reproduced in theoretical spectra generated using FEFF 8.4. The shape resonance peak in $\mathrm{H}_{2}$ or in air was not certain probably because the antibonding levels were below the Fermi level or the shape resonance peaks for $\mathrm{H}$ and $\mathrm{O}_{2}$ adsorbed were similar. Superior turnover numbers were tentatively evaluated for the $\mathrm{Pt}-\mathrm{C}$ replica in the cathode compared to $\mathrm{Pt} / \mathrm{Valcun} \mathrm{XC}-72$ due to the differences of effective contact of Pt with $\mathrm{C}$ versus Pt impregnation on $\mathrm{C}$ and the diffusion efficiency of $\mathrm{O}_{2}$ in replica $\mathrm{Pt}-\mathrm{C}$ powder (see Supporting Information).

Acknowledgment. The authors are thankful for financial support from the Sumitomo Foundation for Basic Scientific Research (No. 070110). The conventional X-ray absorption experiments were performed under the approval of the Photon Factory Proposal Review Committee (No. 2008G167). The Pt $\mathrm{L} \beta_{1}$ emission and high energy resolution $\mathrm{Pt} \mathrm{L}_{2}$-edge $\mathrm{X}$-ray absorption experiments were performed under the approval of the SPring-8 Program Review Committee (No. 2008B1111). The authors thank Dr. Uruga, Dr. Tanida, and Dr. Terada for the adjustment of beamline optics and technical help at SPring-8 and Prof. Kaneko and Prof. Kanoh for the XRD apparatus. This paper is part 31 of a state-selective X-ray absorption fine structure series. 
Supporting Information Available: Supporting text and Figure S1 for PEFC tests. This material is available free of charge via the Internet at http://pubs.acs.org.

\section{References and Notes}

(1) Gasteiger, H. A.; Markovic, N. M. Science 2009, 324 (5923), 48-49.

(2) Zhang, G.; Yamaguchi, T.; Kawakami, H.; Suzuki, T. Appl. Catal., B 1992, 1 (3), L15-L20.

(3) Xuyen, N. T.; Jeong, H. K; Kim, G.; So, K. P.; An, K. H.; Lee, Y. H. J. Mater. Chem. 2009, 19 (9), 1283-1288.

(4) Plomp, A. J.; Schubert, T.; Storr, U.; de Jong, H. P.; Bitter, J. H. Topics Catal. 2009, 52 (4), 424-430.

(5) Du, H. Y.; Wang, C. H.; Hsu, H. C.; Chang, S. T.; Chen, U. S.; Yen, S. C.; Chen, L. C.; Shih, H. C.; Chen, K. H. Diamond Relat. Mater. 2008, $17(4 / 5), 535-541$.

(6) Somanathan, T.; Pandurangan, A. J. Porous Mater. 2009, 16 (4), $459-464$.

(7) Saha, M. S.; Li, R.; Ye, S. Electrochem. Commun. 2009, 11 (2), 438-441.

(8) Chen, C.; Chen, M.; Yu, H.; Lu, S.; Chen, C. Jpn. J. Appl. Phys. 2008, 47 (4), 2324-2329.

(9) Sun, Y.; Zhuang, L.; Lu, J.; Hong, X.; Liu, P. J. Am. Chem. Soc. 2007, 129 (50), 15465-15467.

(10) Sun, C.; Chen, L.; Su, M.; Hong, L.; Chyan, O.; Hsu, C.; Chen, K.; Chang, T.; Chang, L. Chem. Mater. 2005, 17 (14), 3749-3753.

(11) Hayashi, A.; Kitajima, K.; Miyamoto, J.; Yagi, I. Chem. Lett. 2009, 38 (4), 346-347.

(12) Wikander, K.; Hungria, A. B.; Midgley, P. A.; Palmqvist, E. C.; Holmberg, K.; Thomas, J. M. J. Colloid Interface Sci. 2007, 305 (1), 204208.

(13) Joo, S. H.; Choi, S. J.; Oh, I.; Kwak, J.; Liu, Z.; Terasaki, O.; Ryoo, R. Nature 2001, 412 (6843), 169-172.

(14) Hui, C. L.; Li, X. G.; Hsing, I. M. Electrochim. Acta 2005, 51 (4), 711-719.

(15) Prabhuram, J.; Wang, X.; Hui, C. L.; Hsing, I. M. J. Phys. Chem. B 2003, 107 (40), 11057-11064.

(16) Wikander, K.; Ekström, H.; Palmqvist, A. E. C.; Lindbergh, G. Electrochim. Acta 2007, 52, 6848-6855.

(17) Yano, H.; Inukai, J.; Uchida, H.; Watanabe, M.; Babu, P. K.; Kobayashi, T.; Chung, J. H.; Oldfield, E.; Wieckowski, A. Phys. Chem. Chem. Phys. 2006, 8, 4932-4939.

(18) Ng, Y. H.; Ikeda, S.; Harada, T.; Higashida, S.; Sakata, T.; Mori, H.; Matsumura, M. Adv. Mater. 2007, 19 (4), 597-601.

(19) Zhang, J.; Lima, H. B.; Shao, M. H.; Sasaki, K.; Wang, J. X.; Hanson, J.; Adzic, R. R. J. Phys. Chem. B 2005, 109 (48), 22701-22704. (20) Service, R. F.; Voss, D. Science 1999, 285 (5428), 682-685.

(21) Lim, B.; Jiang, M.; Camargo, P. H. C.; Cho, E. C.; Tao, J.; Lu, X.; Zhu, Y.; Xia, Y. Science 2009, 324 (5932), 1302-1305.

(22) Mayrhofer, K. J. J.; Blizanac, B. B.; Arenz, M.; Stamenkovic, V. R.; Ross, P. N.; Markovic, N. M. J. Phys. Chem. B 2005, 109 (30), 1443314440.

(23) Kinoshita, K. J. Electrochem. Soc. 1990, 137 (3), 845-848.

(24) Wei, L.; Wang, B.; Wang, Q.; Li, L.; Yang, Y.; Chen, Y. J. Phys. Chem. C 2008, 112 (45), 17567-17575.
(25) Warren, S. C.; Messina, L. C.; Slaughter, L. S.; Kamperman, M.; Zhou, Q.; Gruner, S. M.; DiSalvo, F. J.; Wiesner, U. Science 2008, 320 (5884), 1748-1752.

(26) Bearden, J. A. Rev. Mod. Phys. 1967, 39 (1), 78-124.

(27) Zschornack, G. Handbook of X-ray Data; Springer: Berlin/ Heidelberg, Germany, 2007.

(28) Izumi, Y.; Obaid, D. M.; Konishi, K.; Masih, D.; Takagaki, M.; Terada, Y.; Tanida, H.; Uruga, T. Inorg. Chim. Acta 2008, 361, 11491156.

(29) Izumi, Y.; Nagamori, H.; Kiyotaki, F.; Masih, D.; Minato, T.; Roisin, E.; Candy, J. P.; Tanida, H.; Uruga, T. Anal. Chem. 2005, 77 (21), 6969-6975.

(30) Izumi, Y.; Masih, D.; Roisin, E.; Candy, J. P.; Tanida, H.; Uruga, T. Mater. Lett. 2007, 61, 3833-3936.

(31) de Groot, F. M. F.; Krisch, M. H.; Vogel, J. Phys. Rev. B: Condens. Matter 2002, 66, 195112/1-195112/7.

(32) Vaarkamp, M.; Linders, H.; Koningsberger, D. XDAP, version 2.2.7 (2006); XAFS Services International: Woudenberg The Netherlands.

(33) Siegel, S.; Hoekstra, H. R.; Tani, B. S. J. Inorg. Nucl. Chem. 1969, 31, 3803-3807.

(34) Ankudinov, L.; Ravel, B.; Rehr, J. J.; Condradson, S. D. Phys. Rev. $B$ 1998, 58, 7565-7576.

(35) Ankudinov, A. L.; Rehr, J. J.; Low, J. J.; Bare, S. R. J. Synchrotron Radiat. 2001, 8, 578-580.

(36) Bazin, D.; Sayers, D.; Rehr, J. J.; Mottet, C. J. Phys. Chem. B 1997, $101(27), 5332-5336$.

(37) Safonova, O. V.; Tromp, M.; Bokhoven, J. A. v.; de Groot, F. M. W.; Evans, J.; Glatzel, P. J. Phys. Chem. B 2006, 110 (33), 1616216164.

(38) Humbolt, F.; Didillon, D.; Lepeltier, F.; Candy, J. P.; Corker, J.; Clause, O.; Bayard, F.; Basset, J. M. J. Am. Chem. Soc. 1998, 120 (1), 137-146.

(39) Terheijiden, J.; Van Koten, G.; Van Beek, J. A. M.; Vriesema, B. K.; Kellogg, R. M.; Zoutberg, M. C.; Stam, C. H. Organometallics 1987, 6, 89-93.

(40) Wang, L.; Johnson, D. D. J. Am. Chem. Soc. 2007, 129 (12), 36583664.

(41) Kruk, M.; Jaroniec, M.; Kim, J. M.; Ryoo, R. Langmuir 1999, 15 (16), 5279-5284.

(42) Glatzel, P.; Bergmann, U. Coord. Chem. Rev. 2005, 249, 65-95.

(43) de Groot, F. Chem. Rev. 2001, 101 (6), 1779-1808.

(44) Izumi, Y.; Nagamori, H. Bull. Chem. Soc. Jpn. 2000, 73 (7), 15811587

(45) Izumi, Y.; Kiyotaki, F.; Minato, T.; Seida, Y. Anal. Chem. 2002, 74 (15), 3819-3823.

(46) Izumi, Y.; Kiyotaki, F.; Seida, Y. J. Phys. Chem. B 2002, 106 (7), $1518-1520$.

(47) Izumi, Y.; Masih, D.; Aika, K.; Seida, Y. J. Phys. Chem. B 2005, 109 (8), 3227-3232.

(48) Izumi, Y.; Glaser, T.; Rose, K.; McMaster, J.; Basu, P.; Enemark, J. H.; Hedman, B.; Hodgson, K. O.; Solomon, E. I. J. Am. Chem. Soc. 1999, 121 (43), 10035-10046.

(49) Koningsberger, D. C.; de Graaf, J.; Mojet, B. L.; Ramaker, D. E.; Miller, J. T. Appl. Catal., A 2000, 191, 205-220.

(50) Bashyam, R.; Zelenay, P. Nature 2006, 443 (7107), 63-66.

(51) Orilall, M. C.; Matsumoto, F.; Zhou, Q.; Sai, H.; Abruña, H. D.; DiSalvo, F. J.; Wiesner, U. J. Am. Chem. Soc. 2009, 131 (26), 9389-9395.

JP909934R 